International Journal of Instruction e-ISSN: 1308-1470 • www.e-iji.net
April $2018 \bullet$ Vol.11, No.2

p-ISSN: 1694-609X

pp. 585-602

Received: 08/02/2018

Revision: 28/02/2018

Accepted: 02/03/2018

\title{
The Reflection of Immigration on School Culture: A Qualitative Study
}

\author{
A. Selcen Arslangilay \\ Dr., Gazi University, Gazi Faculty of Education, Turkey, aslihanselcen@yahoo.com
}

$\mid$

Each organization has its own system of values, beliefs and attitudes that are valid for the schools and it accompanies the concept of school culture, one of the important factors determining the success of a school. Immigration is a phenomenon that leads to great influences in every society. The purpose of this study is to determine what reflections; the Syrian asylum seekers have on school culture in a primary school, which is also used as a Temporary Training Center (TTC) in the capital city of Turkey, Ankara. 12 participants, including 5 teachers, 5 Turkish parents and 2 administrators, participated in the research, which was designed in case study design and in which qualitative data collection and analysis methods were used. The data obtained via the semi-structured interview forms prepared by the researcher were analyzed with descriptive analysis technique. According to the results of the research; after the Syrians came, there were some changes in the school culture. However, since such a massive migration is a very new experience, and school managers are sensitive to this issue and demonstrate democratic leadership features, there have been no major issues in the school. It is thought that the problems will gradually decrease, as experience about immigration increases.

Keywords: school culture, migration, Syrian students, organization culture, temporary training centers

\section{INTRODUCTION}

There is a long history of the concept "culture", which has been started to be used to understand the behavior of human groups. The concept was first used by anthropologists to understand the difference between societies, tribes, national or ethnic groups, and later by social scientists who desired to understand the behavior patterns in business life. In official organizations, everything that affects the opinions, activities and behaviors of the members of the organization, and therefore their performance, is tried to be explained by the concept of culture (Deal \& Peterson, 2009). Culture can also be thought of as a "collective agreement" that distinguishes all organizations from one another and indicates how they should be treated and what attitudes they should exhibit (Cemaloğlu, 2017). It is not so new that schools, as organizations, have a culture of their own. For the first time in 1932, the American sociologist Willard Waller suggested the 
following ideas that are still valid today: Schools also have their own traditions, ceremonies and rules. All these lead to school relationships and behavior (Deal \& Peterson, 2009). In fact, all organizations, including schools, can perform better when they have a system of common values, traditions and rules. It is anticipated that schools, which do not have these features, will not succeed. With the common endeavor of all the participants in the school, the responsibility of learning and teaching, and all these being supported by cultural values, schools will escape the danger of being a learning factory that does not have a soul. Creating a positive and strong school culture can only be achieved with formal or informal leaders who work at school and care about culture and values (Peterson \& Deal, 2009).

Components forming organizational culture can be listed as; language, common values and beliefs, ceremonial events and ceremonies, symbols, stories, legends, important events and persons, and physical environments (Aslan, Özer \& Bakır, 2009; Cemaloğlu, 2017; Peterson and Deal, 2009; Sezgin \& Sönmez, 2017; Yavuz, 2016). The culture that schools possess forms their identities and separates them from others (Yavuz, 2016). Moreover, Cemaloğlu (2017) states that organizations are influenced by external environment as they exhibit open system characteristics and they also affect the external environment. When considered from this point of view, immigration, one of the most important phenomenon of human history has a significant influence on Turkey especially in the last few years and it is important to investigate what is its effect on school culture which exhibits open system characteristics.

According to the International Organization for Migration (IOM) (2011, p. 62), regardless of purpose, duration and type, all population movements that people or groups of people carry out within a country or by moving to an international border can be considered as "migration". These include population movements, economic migrants, displaced persons for a reason such as war, and relocations for different purposes such as family reunification. Therefore, in this study, the word "migration", which refers to the displacement of Syrian asylum seekers, was used.

The "immigration" phenomenon, which has always influenced humanity, has also affected our country throughout its history. When migratory movements before and after the Republic were examined, more than 2.5 million people have come to our country since 1922, apart from the foreigners who came to our country to work and study (İçişleri Bakanlığı Göç İdaresi Genel Müdürlüğü [GIGM], 2015).

On April 29, 2011, 252 Syrian citizens entered our country through the Cilvegözü border gate with "open door" policy practice of our country (GİGM, 2015; Coşkun \& Emin, 2016). Now approximately 3 million Syrian citizens are being hosted in our country (AFAD, 2014). Approximately 260.000 of the Syrian citizens who were admitted and given temporary protection status (Seydi, 2014) live in temporary shelter centers established by AFAD in 10 provinces, while others live outside the settlement centers in many different cities. The important point is that almost half of the 3 million Syrian citizens are from the $0-18$ age group. It is therefore seen that the number of Syrians who will start school and who are in the school age is in a serious proportion (Coşkun \& Emin, 2016). 
One of the most important problems in the countries receiving immigration is the problem of the ones coming to the country to adapt and integrate with that country. The most important thing for this is to learn the language of the hosted country. This can only be achieved through education and it is the most important factor in carrying out the education in a healthy way. While learning the language of the arrival country, it is also important not to forget the mother tongue and continue to be educated with it, which will also help people to adapt in their homeland when they return. Therefore, both the mother tongue and the language of the hosted country should be taught and learnt coordinately.

In addition to the asylum seekers at the borders, the presence of a large number of Syrian citizens in large cities such as Istanbul and Ankara has led to many influences, especially in economic, cultural and social aspects. One of these effects, when the ages of the migrating community is taken into account, is the impact on the school system. The fact that the war in Syria has been going on for a long time and not a solution has been reached, indicates that the Syrian guests who are thought to reside short-term will be long term and that this community, which includes a very large young population, will not return to their countries in the short term. Therefore, our country, assuming that our guests would only be short term residents, decided to take temporary measures not to further exclude their children from education. For this purpose, first in 2012, Syrian volunteer teachers started to give Arabic education at the primary and secondary level through Syria's own curriculum at Temporary Training Centers (TTC), to only those living in the camps who were supposed to return to their countries in a short time. With the ongoing war and the increasing migration wave, in 2013 the Ministry of National Education focused on the policy of providing education also for children outside the camps. Under the "Foreigners and International Protection Law" numbered 6458 issued in 2014, The Temporary Protection Regulation, which entered into force in October 2014, provided access to education, health and welfare services for Syrians living in camps and outside the camp. With the circular titled "Educational Services for Foreigners" dated 23 September 2014 and numbered 2014/21, which guarantees education to be provided to the Syrian children, Syrian children were granted the right for legal registration with foreign recognition documents at schools affiliated to the Ministry of National Education. Still, education services continue to be offered TTC's inside and outside the camp and private schools opened by Syrians (MEB, 2014; ÇOÇA, 2015; Emin, 2016; Coşkun \& Emin, 2016).

When taken into account that organizational culture does not have a fixed structure and can also change over time, and has renewable qualities (Cemaloglu, 2017) it is thought that immigration, which is a process that affects humanity in various ways, also influences the school culture. In this aspect, this research was conducted to examine whether the presence of these students in our country make any change or influence on the cultures of the schools.

When the literature is examined, studies on opinions of the teachers and administrators about the school culture (Aslan, Özer \& Bakır, 2009; Güven, 2015; Paker, 2014; Sabancı, Şahin, Sönmez \& Y1lmaz, 2017; Şahin-Firat, 2010), factors affecting school culture (Demirtaş \& Ekmekyapar, 2012; Şahin, 2010) and metaphorical perceptions of 
teachers and students about school culture (Özan \& Demir, 2011) are seen. Sak1z (2016) conducted a survey with administrators in schools with high immigration in the Southeastern Anatolia Region, which aimed to reveal the attitudes, views and beliefs of them regarding the inclusion of immigrant students in schools. Again, Özdemir (2016) evaluated the influence of foreign students the majority of whom were Afghans attending schools in Sivas on the school climate with the opinions of teachers, administrators and Turkish and foreign students. However, there is no research that specifically examines the reflection of the Syrian immigration on school culture. From this point, the aim of this work is to see if there is any change in pre-migration and postmigration school culture in a school exposed to intense Syrian migration in the province of Ankara, with the largest number of Syrian students, serving as a TTC, from the views of administrators, teachers and parents.

To this aim, detailed answers to the questions below were sought:

According to the views of the administrators, teachers and parents who participated in the interview, with the attendance of the Syrian students to the school; has there been a change in the,

- language spoken at school

- values and beliefs

- school rules

- symbols

- ceremonies

- the specific story of the school

- school's former recognition from the environment and its current recognition?

- if yes, what are the changes and how are they experienced?

The research questions also aimed to reveal the opinions of teachers, parents and administrators about the Syrian students and the problems they have experienced with them.

\section{METHOD}

The Model of the Study

In the research, aimed at assessing the reflection of migration on school culture, based on the views of administrators, teacher and parents, qualitative data collection and analysis techniques were used. In this case study designed study, interview, one of the main data collection tool of qualitative research design was used.

The interview provides the possibility to investigate every aspect with flexibility and gives the possibility to examine it by using probes when necessary. In addition, the interviews are among the basic data collection tools used in studies related to "organizational culture", which is also the main topic of this research (Y1ldirım \& Şimşek, 2016).

\section{Study Group}

The participants of this study are administrators, teachers and Turkish parents in a primary school, in which the highest number of Syrian students are educated in Ankara 
after the border cities, and serves as a TTC. The volunteered administrators, teachers and parents who could provide the data needed for the research, were chosen by purpose. In the study using the maximum diversity sample from the purposeful sampling methods, it was aimed to provide the maximum diversity of the persons who could be the subject of the investigated problem and therefore to be able to reveal the different dimensions of the problem in these varying situations (Yıldırım \& Şimşek, 2016, p. 119).

Volunteered teachers who were thought to have lived the influence of migration on the school culture as they worked in pre- and post-migration periods, which could help them to compare the situation before and after the Syrians arrived, were especially interviewed. Teachers who have been working for a longer period and those who have just started their careers were especially chosen. Likewise, parents who have children who went to the school before the Syrian students came and parents whose children attend and do not attend the same class with Syrian students were purposely chosen. It was also taken into account that both administrators interviewed had worked at the school before and after the migration. Semi-structured face-to-face interviews with 2 administrators, 5 teachers and 5 parents who volunteered to participate in the study were done by the researcher.

\section{Data Collection Tool, Collection and Analysis of Data}

The data collection tool of the research consisted of semi-structured interview forms developed by the researcher. The interview forms were developed in accordance with the purpose of the research, by literature review and taking expert opinions. To determine the validity and reliability of the interview forms after the pilot study, the modified interview forms were presented again to expert opinions and finalized by the Turkish language expert in terms of language accuracy. After the necessary permissions were obtained for the interviews, the interviews were made by the researcher herself. The interviews with the teachers lasted for 10-15 minutes, with the parents about 10 minutes and with the school administrators 20-25 minutes.

To prevent data loss, interviews were conducted using voice recorders by receiving permission from interviewed participants. All participants were assured that the interviews would only be used in this study and that the records could be deleted once the research is completed if they wished. Interviews conducted during the last week of the academic year at a time when students no longer came to school, was done in empty classrooms where they were away from external factors such as noise. For the analysis of the data obtained from the interviews, the voice recordings made during the interviews were transcripted and the obtained data were analyzed by descriptive analysis method. The first step of the descriptive analysis procedure was creating a framework from the research questions to summarize and interpret the data according to the themes. After eliminating the useless data and organizing the data according to the formed framework, all data were organized with the direct quotations to support them and were presented to two experts' views. All these were represented under the findings title (Yıldırım \& Şimşek, 2016, p. 239-240). In the findings and interpretations section, in order to determine which quotation belongs to which participant, codes have been given 
to the participants. For example, T1 refers to the first teacher interviewed, P3 refers to the third parent, and A1 refers to the first administrator interviewed.

\section{FINDINGS}

In this section, answers given by teachers, administrators and parents to the questions directed to them were analyzed and presented in terms of research purposes.

\section{Views regarding whether there is a change in the language used in the school}

The school, which also serves as a TTC, has bilateral education, and after the Turkish students are educated until the afternoon, the Syrian students are taking Arabic education through the Syrian curriculum. Therefore, there are Turkish students in the morning and Arab students in the afternoon at school. Only a few Syrian students in the first grade are educated with other Turkish students but next year all students would be integrated into Turkish classes until the $4^{\text {th }}$ grade of elementary school, and full-time education at the school is on the agenda.

Since there are very few Syrian students who attend the first class together with Turkish students in the morning, teachers working in morning time and the parents have not noticed any changes in the language spoken at the school. They explained the reason as that they come in the morning and that they are not at school at the time when the whole Syrians come to school.

One of the teachers who stated that there was no change in the school's spoken language expressed the problem that they lived in language only during breaks when they are on duty:

"...When we are on duty, Syrian students do not understand what we say, for example they fight a lot. They do not understand what we say, or we don't understand what they say, but we had no big problems. Because there are students who learn Turkish among the Syrians and out of our staff who are Syrians who are solving it easier. We also learnt 'Yallah' so that they enter the class. They understand it. I guess it means 'go', we learnt it this year..." (T4)

All of the interviewed teachers stated that there was no change in the language of the school because of working in the morning and because very few Syrian students were involved in morning groups.

Unlike the Turkish teachers who work only in the morning group, one of the administrators, who is in the school all day long, stated the change they observed at school and on the spoken language was as follows:

“... Before, there was only a Turkish noise, now there is noise in Arabic, and this doubles, triples the intensity because; you do not understand their language... There is a decibel increase... I do not know if it is related to the spices they eat or with the genes, what we call volume is very high, they are also too many in numbers, there are 1101 students in the afternoon... For example, they do not climb the stairs without speaking... They have not yet started to speak Turkish, they still speak Arabic among themselves and you feel this very intensely... Everywhere, anytime Arabic ... You can even forget that you are in a Turkish neighborhood ..." (A2).

Emphasizing that the district where the school is located has also been exposed to the Syrian migrants in a very intense way, the administrator also explained the difficulties 
she had experienced at the time of registration as she did not know Arabic and the Syrian parents did not know Turkish.

The parents who stated that there was no change in the language spoken at school also referred to this that their children are in the morning groups and they did not encounter with the Syrian children who came to school at afternoons. In addition, they stated, even if there are Syrian students in their class, their numbers are very few and as they start to learn Turkish gradually, there is no change in the language of the school.

2. Views regarding whether there were changes in values and beliefs of the school

Teachers who stated that there were some changes in the values and beliefs that existed in the school after the Syrian students came stated that they were more concerned with following the rules of cleaning, respecting the environment and respecting the belongings of others and presented examples from their experiences:

“... They were opening our closets; belongings from our closets were getting lost. As a school, we made padlocks as you see, as a solution. When you left anything, it disappeared. In addition, when we arrived in the morning we found the class very dirty. Breads on the ground... leftovers ... They also had a different spice that they ate, that smelled bad and we felt very uncomfortable with it. In the early days, the parents felt a discomfort. They used to come in before the morning students and disinfect the setting. Then we got used to ..." (T1).

"... I always hear from the parents that they are not like us in a cultural sense... Cleanliness, etiquette, I know we are very different in these sort of things... They leave breadcrumbs, when my students arrive they are disgusted ... Pretzels, breadcrumbs, strange foods I do not know on my computer table... Everyone knows nothing is put on a teacher's table; my students do not even come close to my table ... So I take them with a napkin, after that the kids say 'do not take it teacher, do not throw it away, should we put it in front of the window? It is a sin to throw away food especially bread it in the trash', this time a confusion in the minds of the children begins ..." (T5)

The parents like the teachers, emphasized that they had problems with the cleaning rules especially with the Syrian students who were using the same classes in the afternoon in the school, which had two shifts.

A parent, who is working as a school attendant and whose child had finished the 4th grade, explained according what she has witnessed that some of the values that Syrian children have are different from those of Turkish children:

“... The first 2 years were very nice, our class had belonged to us, because now they are using it afternoon... In terms of cleanliness, the food they eat is very different, they have different cultures ... The bread is being thrown into the trash into the toilet, we collect wraps from the toilets, Turkish children do not do that..." (P2)

Again, the same parent expressed the change she saw in her child studying with the Syrians as follows:

"... My daughter is a gentle, intelligent child; Syrians did not come to their classes. I did not see anything from her, but my son is in the same class with the Syrians... My daughter says 'let's play housekeeping'; he says 'what shall we do with housekeeping!' He is jumping on her back, hitting her... when he used to attend the nursery school he would play with notebooks pencils, with his cars... but now when he thinks about play; blood and thunder... 
There are 6 Syrians in his class, thank God they are submissive but my son sees the others during the break..." (P2)

A parent whose first child has already graduated from this school and the second child is studying with Syrian children, who is also a class mother explained that there are changes in some values:

"... At least, we are in disorder now, they do everything with noisy fighting as they have just came out of war, they do not speak Turkish, they cannot communicate with children ... They take our pens without permission, they tear our books ... We decorate the door, we cannot find that door the next day... I am a class mother, I want 15TL copying and cleaning fee, the Syrian parents say that it is forbidden by religion and don 't pay..." (P5).

Another parent stated taking into account Syrian students do not wear school uniform, that: "Turkish students say 'they do not wear it, why do I wear it', no more respect do the Turkish students have towards school uniform (P3)", so Turkish students had some kind of a change towards this value.

The administrators stated that they had negotiated with the parents and the teachers about their dissatisfaction with the different cultural habits of the Syrians and they no more have problems like this anymore.

\section{Views regarding whether there is a change in school rules}

In the interviews, the teachers and administrators were asked whether there was a change in the school rules after the Syrians came and whether the rules applied to the Turkish students were also applied to the Syrian students. A probe question, whether there was a relaxation in the rules and if, in which rules were added.

Teachers stated that as Syrian students were generally in the afternoon group and that the few Syrian students in the morning group were generally integrated into the school so they have not experienced problems during entry and exit. However although they were no Syrian students in their class, they stated that they experienced some difficulties in applying the school rules due to the "language problem" during duty time.

A teacher described her views in the following way:

"... Sometimes we have difficulties during our duty time, because we cannot communicate with them and they have problems to understand us. We have Syrian officials, for example, they are helping us to get them in, during our duty... I mean they are a bit combative, but because they came out of a war environment... Many of them have a bad temper as they have already lost their mother or father or a close friend during the war. So they are not like our Turkish children, but more combative..." (T1).

Teachers who are aware of the psychology of the children that came to our country to save their war-torn lives relate these to the difficulties children have with the rules.

Again, one of the teachers mentioned a situation, which concerned the morning group but did not interfere with the school rules as follows:

"...We have not experienced a problem in general. However, colleagues who work in the class with Syrian students have suffered very much because they cannot reach them in the sense of language, so in teaching. Syrian children had behavior problems; more combative, more prone to violence than our Turkish students. Otherwise, the school did not have any 
problems in terms of general arrangement; maybe because I did not have any Syrian students, I didn't witness such a problem. However, as I said, my colleagues who have Syrian students in their classes were telling me they had problems. For example, they did not learn, they learned too late, they made it difficult. The biggest problem was behavioral; most of them were children who do not listen to the rules because they tend to violence. In that sense, the course teacher has suffered. Otherwise, there was no disorder in the school system."(T2)

Teachers stated that if the school rules are going to be relaxed, it could be about the cultural habits of Syrians, and in terms of eating and clothing. Another teacher explained that school rules are difficult for Syrian students to apply and that their own arrangements have changed because they do not want to be assimilated:

"... In general clothing or nutrition. Their eating habits are very different. However, we have a regular diet; our students bring their breakfast from home. Syrians do not fit in nutrition, this cannot be changed ..." (T4)

Since the school also functions as a TTC, in the afternoons not only students but also Syrian volunteer teachers are present in the school. When asked about the school rules, Turkish teachers assessed the problems they had with the Syrian teachers in the context of the school rules and explained the problems they experienced at the beginning:

“... In the first year, we were coming across with Syrian teachers. Our shift end overlapped with their shift start time. Sometimes they were early at work because they had things to do, but we have not come across since two years ... They used our glasses at that time, it is nothing nice. It was very disgusting to pick up a glass of anybody, drink water with it, just rinse and put it back. Therefore, we threw away our glasses, as they did not pay attention to cleanliness ... Or, for example, you are sitting in the teachers' room or copying in the photocopy room, they are starting to pray on their prayer rug. Now the floor is not clean, or their clothes are not clean. There is a prayer room in the school; there is a place where they can pray. Of course, s/he will surely fulfill her/his belief. There are also people among us praying, but we pray in the prayer room. Nevertheless, it is not nice to have a Syrian male teacher pray in front of me while I am photocopying there. There were such things... Toilets, for example. We did not want to use the toilet because they did not pay attention to cleanliness. Then not to make any discrimination, we used them anyway. Even if we resisted it, we got used to it..." (T2)

The parents said that Syrian children did not cause any changes in the school rules, but the parent who also worked at the school emphasized the changing situation of the school at the afternoons like this: "In the mornings we do not have any trouble at school, after lunch, a very messy place. I get tired both physically and mentally..." (P2)

Since the administrators are together with the Syrian students who are educated in the afternoons at school, they have to manage a very large number of students who do not speak Turkish and the age range of whom is very large, as opposed to the morning shift teachers and whose age gap is very big.

One of the administrators stated:

"... There are two types of Syrians, those who take co- education with our students, we apply the rules to them, but the second, the so-called TTC students, we cannot apply many of the rules we apply to our Turkish children there. For example, girls and boys are doing separate education; we do not have anything like that. We even separated the girls' and boys' schools ... They are applying the curriculum of the Syrian government ..." (Al). 
The other administrator explained the problems they encountered in applying the rules to the Syrian students who are educated in the afternoons:

"...Our cultures are incredibly different; also we are different from them in education and everything. We apply the rules to those who attend school in the mornings and who are registered to e-school naturally, compulsorily, as long as they understand the teacher... Even with deictic gesture, even we have problems, they have to obey that rule... The group coming afternoon is a very troubled one. The reason is the age range is various. From the second class of primary school to second grade of lycee students, they do not know the language, a different teacher structure, a different culture... and just think that we are trying to apply rules on these, think how we struggle. Or to what extent can we achieve?..." (A2)

The interview results showed that, the school rules are tried to be applied to both groups whereas there has to be some flexibility to the student group studying in the TTCs in terms of clothing and food due to the culture gap, lack of Turkish language and the postwar trauma situations.

\section{Views regarding whether there is a change in the symbols}

In this problem of the study, teacher and student clothing styles, the physical environment of the school, panels and bulletin boards were defined as symbols and with probe questions, the views were taken.

Teachers and the administrators stated that for the prevention of the difficulties that could be faced by the Syrian students, they placed Arabic translations for toilets, school canteen and the classes. The school principal summarized what they have done:

"... Since the first day they arrived, we wrote Arabic to their classes... Arabic words showing the canteen, toilet, girl-boy... So not any Syrian student or parent ever had any difficulties in finding their ways in the school..." (A1)

A teacher explained her own experience when the firstly encountered problems were solved as Arabic translations have been used in panels, boards etc.:

"... We also see the Arabic translations everywhere. Firstly some parents reacted which in turn effected the students; they did not want Arabic words. However when we explained them that it is a normal and must thing do to they accepted, embraced..." (T2)

Another teacher set an example on the value differences for the symbol change in the school:

"We came to school one day and saw some Arabic words on the doors. We asked those who knew, they said it was the translation of class branch, number and name in Arabic. Then, Arabic teachers started writing Arabic on boards. They do not have habit of cleaning the board after using it. They even do not have a board eraser, they always use napkins but leave the napkin unclean... When the Turkish students arrive at their classrooms in the morning they see lots of Arabic written on the board. They ask what could be written there. They started to wonder about it. 'Teacher, Syrian friend said something to me in the break, I wonder if he swore?'... I even wonder may be the child would swear to me if I even make a sour face to him/her. I cannot understand this as I have no Arabic... With the help of these Arabic translations they can now find the canteen, not use the teachers' toilets which at first they could not understand..." (T5)

The other administrator also stated that at first, there were some reactions towards the change of symbols in the school but they were all solved. When the researcher asked 
about the physical change in the school and she said, "I saw the Arabic words on the toilets", the administrator replied "... you have seen the answer of the question... We changed many of the signs... For example, at the entrance of the classes, there are Arabic writings, the parents reacted extensively to them, not the students, as they are small in age... However, not only that, but when you look at it as a symbol, for example their clothes and ours do not match each other at all..." (A2). Therefore, the administrator stated that Arabic expressions have been started to be used and mentioned the differences in clothing styles.

Another teacher, referring to the dressing situation, stated what she observed about the subject as follows:

"... They differ from us in terms of clothing, there are Syrian children who wear school uniforms, but also who do not, and there are children who come with pajamas and sleeping bags. My kids are laughing a lot... There is no concept of clothing like ours. Maybe because of their financial situation... Very different in terms of culture, they veil in early years but this

is different for our students... To our children, it looks a bit different in appearance..." (T3)

A teacher who stated that despite the fact that the school's formal dress was "uniform", a change was observed with the Syrians in this situation, which she interpreted as a desire not to obey our rules:

"... Of course you feel some change; we had a practice in our school; to wear uniform; they do not wear uniforms, 'we don't have' they say. You cannot do anything, s/he cannot come naked. So, you have to buy one for that student or s/he comes without uniform with casual clothes. This time, Turkish students see them and say 'why do not we wear casual clothes?' So, they changed many things. Why? I think that they don't want to obey the rules..." (T1)

Parallel to the views of teachers and administrators, the parents stated that their children reacted especially to the students in the afternoon group who are without uniforms in the form of "why do not we come to school free like them?". However, the administrator exemplified the fact that the Syrian students who are in the morning group and studying with the Turkish students differed in this aspect and that they adapted to the dress code because they are happy to be in a school and in a country, which treats them well:

"... Those Syrian students attending the morning group, wore the same clothes with our students in the Children Day (April, 23) just the girls had headscarves, the boys were the same with the Turkish. Even the teachers did not know that they were Syrian, I told them. They were much more amused than our Turkish children were. I said 'this child won't go back, because s/he is very happy here'. Because s/he knows that they are accepted here..." (A1).

\section{Views regarding whether there is a change in the ceremonies of the school}

Celebrations are among the components of organizational culture and school culture. In terms of our country, we sing the National anthem in the mornings of Monday and afternoons of Fridays.

Administrators, teachers and parents stated that no change was experienced in the ceremonies. Just in the beginnings Syrians were perceived as being disrespectful to these ceremonies that were foreign to them, but after they were informed that everybody have to stay silent during these ceremonies, the problem was solved. 
One of the administrators told how they all solved a problem in this respect as the whole school. Moreover, realizing that their culture is also respected, Syrians began making their own ceremonies before starting their courses:

“... When they first arrived, as they didn't have any idea while we were singing the National Anthem, as they don't know what it is, they continued their conversations... However, we, all the school personnel, teachers told them how to behave during these ceremonies... As time went by, they also showed the respect we showed. On Fridays they make their own celebrations, a child dictates them some kind of worship or something like our student oath..." (A1)

The other administrator explained that they did not expect the Syrians who had are educated at TTCs especially, to attend at the ceremonies, however they did:

“... We don't except the Syrians in the TTC to attend our own national ceremonies, however they attend. For instance, last year in April 23, National Children day, a Syrian child read a poem called 'What it is like to be a child in Syria'. He made everybody cry, really everybody cried. The poem started as; 'Do you know what it is like to be a child in Syria...' He told the effects of the war, the reports of guns so effectively; it is a child who wrote the poem, I think one of our Syrian elder students. You know in this school there is TTC for children until high school grade two whereas the morning regular school is until 4th grade primary school. Therefore, they don't attend our ceremonies usually, however when they do, we see the difference. The ceremonies are more beautiful, a different environment is formed, and we welcomed them, embraced them, you do something altogether, their participation contributed us positively, not negatively... Monday mornings they are not at school so they saw our ceremonies first in Friday afternoons... Initially it was perceived as disrespectfulness but it was because they didn't know it, after we informed and warned them they are very respectful..." (A2).

Both administrators emphasized that respect to cultural values and mutual tolerance added value to the school's intercultural environment.

6. Views regarding whether there is a change in the story of the school

According to all interviews, it was stated that the clearest change in school culture by migration was the change in the school's story. In respect to the name of the school which reflected the Turkish history, it now is referred to differently with the Syrian residents of the street. The administrator defined the situation as follows:

“... When the Syrians arrived, they first didn't call the school Aleppo but they named the street as Aleppo... Therefore the name of the school is referred to the 'School of the Syrians', this is the new story of our school... The scientific name is TTC; but who knows it so; may be just the ones who know the matter, may be the bureaucrats, but colloquially if you ask the ordinary people, they would answer 'The School of the Syrians'. But the reason is; we have 520 Turkish students whereas approximately 1300 Syrian students, so it is normal to be called like this if you compare the numbers..." (A2)

A teacher explained that they attracted the attention of the public as the high amount of Syrian students over Turkish students as follows:

"... We are a school, which had hit the headlines in newspapers and news. The headings are usually like this: 'A Syrian school in the middle of the capital city!'... We have twice as more Syrian students in the middle of the capital city. Therefore, we attracted attention from abroad, everywhere. We had many visitors, District Governor, District Director of National 
Education, Mayor, we drew great interest. But obviously we were appreciated, they came with lots of thanks. Even this was officialized, we were awarded. As they stated that, 'we could achieve this process thanks to you'... We are known as 'Syrian School' unfortunately, our story has really changed so much as they are so more than us in numbers..." (T3)

Another teacher stated that their school is known as "The Syrian School" and said "... the story of the school: our biggest story is now being known as Syrian School. 'Where do you work? ': 'In the Syrian school!' everybody recognizes then!" (T4)

Again, another teacher stating that the school is recalled as "Syrians School" expressed her ideas as: "It was among the good schools in this neighborhood, but now doesn't seem like a Turkish school I think, they call it Syria School. When the teachers wanted to apply for appointment and search the school in internet, they see it as Levant School; so you decide whether this is a positive or negative prestige. In the past it was a normal and good school..." (T5).

Another teacher also emphasized the same situation and said: "... Aleppo School, when the Syrians are on the collective taxi, they say 'I will take off in Aleppo' and everybody knows it. The neighborhood in which the school is located is Aleppo and here is the Aleppo School. They call it so. Even if it is not a formal thing I hear in the buses and shared taxis...” (T1).

The parent who is working in the school stated her views as: “... Now Syrian School, for instance our teacher just arrived, she had searched on the web and saw as Syrian school, so she came very indeterminably and with fear..." (P2) and emphasized the observable changing story of the school.

7. Views regarding whether the school is preferred by Turkish students and parents anymore

It is a fact that the cultures the organizations have and being known in the environment could be their reason of choice (Cemaloğlu, 2017). Schools', as organizations, choice reasons could be shaped according to the target audience thus the students and parents' perceptions about the school. Therefore, it is more important for a school, which didn't have any migration experience before, how the preferences are effected. The fact seen in this study that the story of the school's change because of migration also effects the preference situation of the school.

All interviewed teachers, parents and administrators emphasized the effect of the Syrian population in the neighborhood. The parent who has been living in the same street since she was born and working in this school with her two children educated in the school emphasized the change in the preference of the school as follows:

“... I am warm-blooded, I speak with everyone as I know everyone in the street, but now I am feeling myself as a foreigner in my own street... When I see someone I know, I become very happy as if I saw some citizen abroad... Would my son continue in this school? The teacher, friends are very good but if I had a chance I would go away, after 31 years I would even leave my neighborhood, I even can't open my balcony door, their noisy clamor, and the smell of their cuisine..." (P2)

Another parent said:

"... I can't send to another school, the other schools are also Syrian, let's say the school is okey, than what would we do with the neighborhood? Everyone around me is Syrian... My family once decided to buy a house here, but my father said 'What would I do here, everywhere is Syrian' and gave up..." (P3). 
Similarly, another parent stated that her child would compulsorily attend this school as they bought a house here with bank credit (P5).

The important point is that all parents are just disturbed by the high population of Syrians, not the teachers or administration. On the contrary, they are very pleased with the teachers and administrators. They said, "Our teachers are very good, and the principal, thank God; we have no problems in terms of the school but Syrians are too many in here".

All of the teachers stated that with the possibility of Syrians" "risk of lowering the success" in the school, they think the school which was preferred in the past won't be preferred anymore like in the past. Teachers also emphasized that they are very pleasant with the school, their colleagues, and the administration and explained that it was the positive and successful attitude and continuous support of the administration that made them continue working in this school. The only problem for the teachers is to have to cope with many Syrian students and the fear that they will have problems when the TTC is closed and all these children will be integrated to their classes. Two teachers explained their views as:

"... We were so happy with our school, the friend environment, the administration, the peace and the sincerity in the school. This part is still the same, our work environment, relationships with colleagues and administration, but..." (T4)

"... Instead of working with Turkish students, it is really difficult to cope with students with language constrains as a teacher..." (T3)

Taking into account that these teachers, educating the students with post-war trauma are exposed to a secondary trauma (ÇOÇA, 2015), the explanations of a teacher in this respect and the effect of this to school preference is worth remarkable:

"... This is not a positive change, this huge number of Syrians into our school made us depressed. I think that we are working under hard conditions. I believe that we have a special privilege..." (T2)

One of the administrators who registers the students, unlike the parents and teachers, stated that the school is still preferred as "... In the first time, those whose children were successful took their children from the school... However, now everybody desires to register their children to our school, which makes me really happy, of course thanks to our staff and administration..." (SA2). So, emphasized the positive effects of the teachers and the administration.

\section{DISCUSSION AND SUGGESTIONS}

Hosting many Syrians due to our open-door policy and understanding this is not a temporary process, brought together the need for the education of these people more than half of which consist of young population. So, our country is faced with a large massive migration wave and experiencing a new situation and trying to make many attempts.

As migration, one of the oldest phenomenon of human history, is the basic fact of change (Adıgüzel, 2016), the reflection of this change to education and therefore schools is inevitable. In this study, it was aimed to investigate the reflection of migration to a school that is used as a TTC in which Turkish students are educated in the mornings and Syrians in the afternoon. As only the small number of first grade Syrian students are 
educated with Turkish students with the new practice of Ministry of National Education, teachers stated no difference in the language spoken in the school. Teachers emphasized that especially in duty times they faced problems because of language and one teacher explained that she learnt an Arabic word "yallah" that means "go" and this way she could tell the Syrian students to go to their classes after the break. The fact that the important factor in bilingual and intercultural education, that the teacher's learning a few words of the migrants, has a positive effect on the migrant students' psychology and is a good improvement here. When the migrant child hears some words in her/his mother language from the teacher, s/he would exhibit positive attitudes to the migrated country and her/his own identity (Bingöl-Arslangilay, 2013; Nakipoğlu-Schimang, 2011).

Parents, the children of whom are educated together with the Syrians stated that no difference in the school's language was seen as the number of these children are very few in the first grade. However, school administrators who are at the school the whole day stated that Arabic noise has been added to a Turkish noise in the school.

Another important component of the school culture, "values", were seen not positively changing by teachers and parents in terms of rules of cleaning, respecting others' belongings and environment, which they thought as a result of cultures' being very different from each other. The similar reasons of the negative experiences between Syrian and Turkish teachers were significantly solved with the positive intervention of the school administrators and mutual dialogue and consensus. In this respect, school administrators could be stated as leaders who manage an organization culture that effects the school culture positively (Cemaloğlu, 2017). Moreover, the fact that teachers, parents, students and school administrators' starting to get to know this new culture and realizing the similarity and differences and learning something about the Syrian culture is important in terms of intercultural education.

In "rules", among the important components of school culture, no big problems are seen due to the few number of Syrians in the morning, however because of the cultural differences in dress-code and cuisine some flexibility is done is stated by all interviewed participants. Similarly, school administrators stated that they couldn't apply the same rules of the Turkish students to Syrians being educated in TTC's.

In terms of "symbols", it is noteworthy that Arabic is written in all environments of the school to prevent the problems encountered by Syrians and not to make them far away from their cultures. No changes in the "ceremonies" of the school was seen. Although Syrians were perceived as being disrespectful to the ceremonies which they had no idea of, after they learnt the significance and the meaning, they respected them. Similarly, Syrians continued to practice their own ceremonies. Also stated by Taneri and Tangülü (2016), speech made by a Syrian student with the participation of teachers, administrators and parents will develop the attitudes of Turkish students towards Syrian students. In the school, the participation of Syrian students to Children Day by reading poems would help Turkish students to develop empathy towards them as well as a very important contribution to the school culture positively. 
It is understood in all the interviews the highest reflection of Syrian migration on school culture is in the "story" of the school. Named after an important Turkish historical person, the school is now referred to as "Syrian School" or "Aleppo School". They all explained the reason as the huge Syrian population in the school and the neighborhood.

The fact that perceptions towards school's quality would effect school culture (Demirtaş, 2010) is thought by teachers and parents that the school won't be preferred anymore could be seen a negative effect on school culture. However, this only stems from just a "worry" and no success failure is seen in the school. The huge population of Syrians lead such a thought in teachers and parents. Teachers' worries in language problems, so they won't be happy in their work (Ekici, 2015) leads to the negative thoughts of teachers towards the preference of the school.

As migration is a phenomenon effecting the whole humanity, it is thought to effect the school and its culture. At the end of this study, it is seen that migration has reflections on a primary school in the capital city of Turkey which is also used as TTC. Owing to the longer professional seniority of the administrators, their leadership skills, the good relationship between the administration and parents which is reflected into the positive teacher-parent relationship indicates that these positive practice will continue in the future. The fact that this very new experience is managed positively shows that the problems will diminish. This implies the correct choice of Ministry of Education by choosing this school. It is suggested that trainings for parents about migration and its psychology could be given, seminars by the administrators of this school to other schools with the same situations could be guiding them. It is also suggested that this study is repeated in the same school, which will no longer be a TTC but coeducation school and see how the school culture is affected in the new situation.

\section{REFERENCES}

Adıgüzel, Y. (2016). Göç sosyolojisi. [Migration sociology] Ankara: Nobel.

AFAD (T.C. Başbakanlık Afet ve Acil Durum Yönetimi Başkanlığı). (2014). Suriye'den Türkiye'ye nüfus hareketleri: Kardeş topraklarında misafirlik. [Population movements from Syria to Turkey: Visit in fellow land] Retrieved 25 June, 2017 from https://www.afad.gov.tr/upload/Node/3931/xfiles/webformatisuriyedenturkiyeyenufusha reketleri.pdf.

Aslan, M., Özer, N., \& Bakır, A. A. (2009). Okul kültürüne ilişkin yönetici ve öğretmen görüşleri: Nitel bir araştırma. [Administrators' and Teachers' Views on School Culture: A Qualitative Study] İlköğretim Online, 8(1).

Bingöl-Arslangilay, A. S. (2013). 3. kuşak Türk çocukları ve iki dilli-iki kültürlü eğitim modelleri (Hessen Eyaleti Koala Projesi). [Third generation Turkish children and bilingual bicultural education models: Hessen State KOALA Project] Unpublished PhD Thesis, Gazi University, Ankara.

Cemaloğlu, N. (2017). Örgüt kültürü. [Organization culture] Retrieved 10 May, 2017 from http://www.kamudanhaber.net/orgut-kulturu-makale,3399.html. 
Coşkun, İ., \& Emin, M. N. (2016). Türkiye'deki Suriyelilerin eğitiminde yol haritası. Firsatlar ve zorluklar. [Route map in the education of Syrians in Turkey. Opportunities and challenges] (Seta Yayınları 69). Ankara: Turkuvaz Matbaacılık.

ÇOÇA (İstanbul Bilgi Üniversitesi Çocuk Çalışma Birimi). (2015). Suriyeli mülteci çocukların Türkiye devlet okullarındaki durumu. Politika ve uygulama önerileri. [The situations of Syrian refugee students in Turkish state schools. Politics and practice suggestions].Retrieved 30 June, 2017 from http://cocuk.bilgi.edu.tr/wpcontent/uploads/2015/09/Suriyeli-Cocuklar-Egitim-Sistemi-Politika-Notu.pdf.

Deal, T. E., \& Peterson, K. D. (2009). Shaping school culture. Pitfalls, paradoxes, and promises. (2nd edition). USA: Josey Bass.

Demirtaş, Z., \& Ekmekyapar, M. (2012). İlköğretim okulu yöneticilerinin değerlere dayalı yönetim uygulamalarının okul kültürüne etkisi. [The Effect Values-Based Management Practices of Primary School Principals on the School Culture] Kuram ve Uygulamada Ĕ̈itim Yönetimi Dergisi, 18(4), 523-554.

Demirtaş, Z. (2010). Okul kültürü ile öğrenci başarısı arasındaki ilişki. [The Relationship between School Culture and Student Achievement]Eğitim ve Bilim, 35(158).

Ekici, F. (2015). Çocukların göçle birlikte yaşadıkları eğitim sorunları üzerine bir inceleme. [Investigation of the educational problems with migration] In Disiplinlerarası Göç ve Göç Politikaları Sempozyumu. 29-30 Mayıs 2015 (Ed.: Canatan, K., Birinci, M., Çağlar, İ., Kryvenko, Y., Öksüz, S., \& Altun, F.). İstanbul: Elma Matbaası.

Emin, M. N. (2016). Türkiye'deki Suriyeli çocukların eğitimi: Temel eğitim politikaları. [Education of Syrian children in Turkey: Basic education policies] (Seta Yayınlar1 153). Ankara: Turkuvaz Matbaacılık.

GİGM (İçişleri Bakanlığı Göç İdaresi Genel Müdürlüğü). (2015). Göç tarihi. [Migration history] Retrieved 27 May, 2017 from http://www.goc.gov.tr/icerik/goc-tarihi_363_380\#.

Güven, Y. (2015). Lider öğretmenlerin okul kültürüne etkileri. [Effects of leading teachers on school culture] Unpublished Master's Thesis, Marmara University, İstanbul.

IOM (International Organization for Migration). (2011). Glossary on migration. (2nd edition). Switzerland: IOM.

MEB. (2014). Yabancılara yönelik ĕgitim-öğretim hizmetleri. [Education and training services for http://mevzuat.meb.gov.tr/html/yabyonegiogr_1/yabyonegiogr_1.html

foreigners]

Nakipoğlu-Schimang, B. (2011). Das Frankfurter Modell zur Mehrsprachigkeit. In: Europa braucht Freiheit, Vielfalt, Neugier-Zusammenleben und Integration in der Stadt der Zukunft (s. 95-98). Tagungsreader zum Kongress der Hessischen Europaschulen. Wiesbaden: Druckkollektiv Gießen.

Özan, M. B., \& Demir, C. (2011). Farklı lise türlerine göre öğretmen ve öğrencilerin okul kültürü metaforu algıları. [The Perceptions of Students and Teachers Related to School Culture Metaphor According To Different High Schools] Firat Üniversitesi Sosyal Bilimler Dergisi, 21(2). 
Özdemir, Ç. (2016). Sivas ilinde öğrenim gören yabancı uyruklu öğrencilerin okul iklimine etkisine ilişkin görüşlerin incelenmesi. [The study of the views regarding the impact on school climate of foreign students in the province of Sivas] Unpublished Master's Thesis, Cumhuriyet University, Sivas.

Paker, A. N. (2014). Çeşitli liselerde görev yapan öğretmen ve yöneticilerin okul kültürüne ilişkin algıları. [Perceptions related to school culture of teachers and school administrators who work in a various high schools] Unpublished Master's Thesis, Okan University, İstanbul.

Peterson, K. D., \& Deal, T. E. (2009). The shaping school culture fieldbook. USA: Josey Bass.

Sabancı, A., Şahin, A., Sönmez, M. A. \& Yılmaz, O. (2017). Views of school managers and teachers about school culture. E-International Journal of Educational Research, 8, 1, 28-45 DOI: $10.19160 / 5000186332$

Sabancı, A., Şahin, A., Sönmez, M. A., \& Yılmaz, O. (2017). Views of school managers and teachers about school culture. E-International Journal of Educational Research, 8(1).

Sakız, H. (2016). Göçmen çocuklar ve okul kültürleri: Bir bütünleştirme çalışması. [Migrant children and school cultures: An integration study] Göç Dergisi, 3(1), 65-81.

Seydi, A. R. (2014). Türkiye'nin Suriyeli sığınmacıların eğitim sorununun çözümüne yönelik izlediği politikalar. [Policies of Turkey Regarding the Solution of Educational Problems of Syrian Refugees] SDÜ Fen Edebiyat Fakültesi Sosyal Bilimler Dergisi, 31, 267-305.

Sezgin, F., \& Sönmez, E. (2017). Örgüt kültürü ve iklimi. [Organization culture and climate] In Örgütsel davranış ve yönetimi (Ed: Servet Özdemir ve Necati Cemaloğlu). Ankara: Pegem Akademi.

Şahin-Fırat, N. (2010). Okul müdürü ve öğretmenlerin okul kültürü ile değer sistemlerine ilişkin algıları. [Principals' and Teachers' Perceptions about School Culture and Value Systems] Ĕgitim ve Bilim, 35(156).

Şahin, S. (2010). Okul kültürünün bazı değişkenler açısından incelenmesi. [An Investigation of School Culture with Respect to Some Variables] İlköğretim Online, 9(2).

Taneri, A., \& Tangülü, Z. (2016). İlkokul 4. sınıf öğrencilerinin sığınmacılara bakış açlarının incelenmesi. [Examination of the perspectives of the 4th grade students' to the refugees] Adlyaman Üniversitesi Sosyal Bilimler Enstitüsü Dergisi, 1(4), 187-214.

Yavuz, M. (2016). Yeni nesil okulun kavramsal inşas1. [The conceptual construction of new age school] In Yeni nesil okul, araştıran okul. (Ed.: Mustafa Yavuz). Konya: Eğitim Kitabevi.

Yıldırım, A., \& Şimşek, H. (2016). Sosyal bilimlerde nitel araştırma yöntemleri. [Qualitative research methods in social sciences] (Genişletilmiş 10. Bask1). Ankara: Seçkin Yayıncılik. 